\title{
Review \\ Improving Natural Enemy Selection in Biological Control through Greater Attention to Chemical Ecology and Host-Associated Differentiation of Target Arthropod Pests
}

\author{
Morgan N. Thompson ${ }^{1}\left(\mathbb{D}\right.$, Raul F. Medina ${ }^{1}\left(\mathbb{D}\right.$, Anjel M. Helms ${ }^{1,2} \mathbb{D}$ and Julio S. Bernal ${ }^{1, *(\mathbb{D})}$ \\ 1 Department of Entomology, Texas A\&M University, College Station, TX 77840, USA; \\ mthompson@tamu.edu (M.N.T.); rfmedina@tamu.edu (R.F.M.); amhelms@tamu.edu (A.M.H.) \\ 2 Ecology and Evolutionary Biology Program, Texas A\&M University, College Station, TX 77840, USA \\ * Correspondence: juliobernal@tamu.edu
}

check for

updates

Citation: Thompson, M.N.; Medina, R.F.; Helms, A.M.; Bernal, J.S. Improving Natural Enemy Selection in Biological Control through Greater Attention to Chemical Ecology and Host-Associated Differentiation of Target Arthropod Pests. Insects 2022, 13, 160. https://doi.org/10.3390/ insects13020160

Received: 22 December 2021

Accepted: 31 January 2022

Published: 2 February 2022

Publisher's Note: MDPI stays neutral with regard to jurisdictional claims in published maps and institutional affiliations.

Copyright: (C) 2022 by the authors. Licensee MDPI, Basel, Switzerland. This article is an open access article distributed under the terms and conditions of the Creative Commons Attribution (CC BY) license (https:// creativecommons.org/licenses/by/ $4.0 /)$.
Simple Summary: Some species of insect herbivores can feed on a wide variety of plant species. Over evolutionary time, insect herbivores can associate preferentially with different host-plant species, which frequently leads to genetic divergence between populations of an herbivore species. This phenomenon, referred to as host-associated differentiation (HAD), not only affects insect herbivores, but can also impact their associated natural enemies, particularly predatory or parasitic insects, which are responsible for biological control in agroecosystems. Although the mechanisms underlying HAD in populations of herbivores and associated natural enemies remain underexplored, we argue that the chemical communication between plants, herbivores, and natural enemies likely plays a major role. Chemical cues emitted by plants and insect herbivores influence natural enemy foraging behavior, and divergent chemical cues can lead to natural enemy HAD, ultimately shaping biological control. In this synthesis paper, we explore how the chemical ecology of HAD could influence classical, conservation, and augmentative biological control, and propose research agendas to further biological control efficacy through natural enemy selection.

\begin{abstract}
Host-associated differentiation (HAD) refers to cases in which genetically distinct populations of a species (e.g., herbivores or natural enemies) preferentially reproduce or feed on different host species. In agroecosystems, HAD often results in unique strains or biotypes of pest species, each attacking different species of crops. However, HAD is not restricted to pest populations, and may cascade to the third trophic level, affecting host selection by natural enemies, and ultimately leading to HAD within natural enemy species. Natural enemy HAD may affect the outcomes of biological control efforts, whether classical, conservation, or augmentative. Here, we explore the potential effects of pest and natural enemy HAD on biological control in agroecosystems, with emphases on current knowledge gaps and implications of HAD for selection of biological control agents. Additionally, given the importance of semiochemicals in mediating interactions between trophic levels, we emphasize the role of chemical ecology in interactions between pests and natural enemies, and suggest areas of consideration for biological control. Overall, we aim to jump-start a conversation concerning the relevance of HAD in biological control by reviewing currently available information on natural enemy HAD, identifying challenges to incorporating HAD considerations into biological control efforts, and proposing future research directions on natural enemy selection and HAD.
\end{abstract}

Keywords: biological control; host-associated differentiation; chemical ecology; insect pest management

\section{Introduction}

Symbiotic associations can influence speciation and generate biodiversity [1-3]. These associations encompass a wide range of interspecies interactions, from mutualism to 
commensalism to parasitism. For parasitism, coevolution between host and parasite results in highly specific interactions that promote parasite access to host resources [4]. Parasites adapt to evade or manipulate the immune system of specific host species for their own benefit [5]. Host specialization is common for parasitic insects, including natural enemies of herbivorous insects, such as parasitoids, which typically evolve to evade immune responses of specific insect hosts [6-8]. Functionally, insect herbivores are parasites of the plants they feed upon. Most herbivores specialize on a narrow range of host plants [9-12], evolving mechanisms to detoxify, suppress, or avoid host-plant defenses [13]. For both herbivores and their natural enemies, host detection and acceptance during foraging are critical processes for the initiation of parasitism, and both processes are mediated by chemical cues [14]. Parasites develop heightened capacities over evolutionary time to recognize highly specific, host-associated chemical cues, allowing them to distinguish host from non-host, which drives the evolution of host specialization.

Despite the prevalence of host specialization in parasitic insects $[8,9,15]$, host shifts often occur and lead to the exploitation of new host species [16]. Host shifts can provide enemy-free space [17], reduce intra- and interspecific competition [18], and even increase access to nutrients [19]. In the most extreme cases, genetically divergent populations within a species can evolve to preferentially occur on different host species, and this could represent an initial step towards speciation. This phenomenon is referred to as host-associated differentiation (HAD) [20-22]. HAD is the product of reproductive isolation occurring over evolutionary time as individuals mate nearly exclusively with conspecifics associating with the same host. Host-associated mating exacerbates genetic differences between populations due to selection, genetic drift, and mutation. Due to their relatively short generation times, some insects may rapidly develop HAD [23], with evidence suggesting that insects can evolve to exploit novel hosts within as little as 20 years (equivalent to 40 generations) [24]. Diverging host use across populations requires the evolution of differences in multiple traits related to detecting and responding to novel host-associated chemical cues [25]. In agroecosystems, HAD can influence populations of herbivorous insect pests and their associated natural enemies [23]. Understanding the ecological factors underlying HAD in agroecosystems could inform biological control implementation. Here, we review how chemical ecology can help to delineate the mechanisms underlying natural enemy HAD, and discuss implications for biological control.

Although geographic isolation of populations associated with different hosts can contribute to evolution of HAD, most of the available evidence points to the occurrence of HAD among populations living in sympatry [26]. Sympatry indicates that gene flow can occur between divergent populations but HAD reduces gene flow due to preferential mating between individuals associating with the same host. For instance, sympatric pea aphid (Acyrthosiphon pisum) populations exhibit HAD across host plants that frequently co-occur in nature [27], and since pea aphids exclusively mate on host plants, host choice correlates with assortative mating between host-associated individuals and structures genetic divergence among pea aphid populations [28-30]. A number of factors may contribute to HAD evolution and maintenance in populations living in sympatry. First, host-associated populations are linked to host phenology and if phenology varies across host species, this can result in resource acquisition at different times and thereby restrict mating to the same host-associated individuals. For example, two sister species of live oak (Quercus virginiana and $Q$. geminata) exhibit distinct budbreak phenology, which drives HAD in a gall-forming wasp species despite sympatry in the corresponding wasp populations [31]. Second, feeding mode may drive HAD evolution, and endophagous feeding, such as by gall formers and leaf miners, appears to more frequently lead to HAD compared to other feeding modes [23]. Third, recent colonization of novel host species can promote HAD, particularly if novel hosts are biologically similar to hosts already exploited. For example, potato (Solanum tuberosum) was domesticated in South America, and following the introduction of potato to North America, Colorado potato beetle (Leptinotarsa decemlineata) expanded its host range to feed on potato. Prior to the introduction of potato, Colorado potato beetle 
was already pre-adapted to exploit solanaceous plants, illustrating how pre-adaptation can contribute to HAD establishment [32]. Fourth, host fidelity, or the tendency of adults to return to the same host species used during early development, can also contribute to $\operatorname{HAD}[33,34]$. For insects, host fidelity generally equates to females ovipositing on the same host species they consumed as immatures. Although the factors described here are not an exhaustive list of all possible scenarios leading to HAD in sympatry, each highlighted factor requires differentiated herbivore populations to evolve unique host location and acceptance traits, and these traits correspond predominantly to detection of divergent chemical cues.

For the HAD of insect herbivores, associating with different host-plant species requires evolving the capacity to discriminate between semiochemicals produced by divergent host plants or herbivore populations. Semiochemicals are broadly classified as chemical signals or cues emitted by organisms that elicit responses in receiving organisms: when receivers and emitters are within the same species, the semiochemical is a pheromone, whereas if they are of different species, the semiochemical is an allelochemical (e.g., kairomone). Thus, pheromones communicate messages to members of a same species, and for insect herbivores, aggregation pheromones indicate the location of a suitable host plant to conspecifics. Although pheromone emissions are typically thought to be under strong selective pressure, there are instances in which pheromone emissions diverge within a species, such as aggregation pheromones across two distinct populations of western pine beetles [35]. Divergence in pheromone emissions within an herbivore species may correspond to populations associating with different host plants. In such cases, conspecifics responding to pheromone emissions of a host-associated population drive assortative mating and further differentiate populations [36].

Similar to pheromones, kairomones can reveal the presence of a suitable host plant to herbivores, thus modifying herbivore behavior, and likely promoting herbivore HAD. Plant volatiles or other secondary metabolites convey the identity and suitability of a host plant to foraging herbivores. After locating a suitable host, herbivore feeding triggers the production of herbivore-induced plant volatiles (HIPVs), which are specific to the identity of the attacking herbivore [37]. Foraging herbivores can detect HIPVs and use these cues to assess the acceptability of a host plant [38-40]. During the early evolution of HAD, divergent populations of herbivores presumably adapt to recognize and respond to different hostplant chemical cues. For instance, host-associated pea aphids are stimulated by chemical cues from their respective host plants, indicating that host-plant semiochemicals promote herbivore HAD through attraction towards hosts rather than repellence from non-hosts [41]. Similarly, host-plant primary and secondary metabolites strongly differ across plant species attacked by South American fruit flies (Anastrepha fraterculus) that exhibit HAD [42]. While this points toward host-plant cues as drivers of HAD, male pheromone emissions are also divergent and contribute to fruit fly HAD [42], highlighting the complex reality that hostand conspecific chemical cues may simultaneously underpin HAD.

Natural enemy populations may also be subject to the evolution of HAD because they typically live in close association with their herbivorous hosts. For example, the evolution of HAD in herbivore host species may drive co-diversification of associated natural enemies, which is termed "sequential radiation" [43]. Apple maggot (Rhagoletis pomonella) and its associated parasitoids is the best studied example of natural enemy HAD in agricultural systems [44-46]. Herbivorous apple maggots use fruits for mating and oviposition, and populations show HAD between apple (Malus domestica) and hawthorn (Crataegus spp.) hosts. Apple maggot HAD is maintained in part by host fidelity through the attraction of apple maggots to natal fruit volatiles over non-natal fruit volatiles. Apple maggot HAD dictated the co-diversification, and the resulting natural enemy HAD of three species of apple maggot-specific parasitoids [47]. Interestingly, those natural enemies also exhibit strong preferences for fruit volatiles from their natal hosts, and avoid non-natal host volatiles [47]. Reciprocal rearing experiments for one parasitoid wasp species, Diachasma alloeum, further demonstrated a genetic basis for volatile preference, indicating that attraction to these cues is a trait under divergent selection across D. alloeum populations [47]. Relatedly, because 
HIPVs are released exclusively upon herbivory and attract natural enemies to host plants to eliminate herbivores, they serve as consistent and reliable foraging cues, and likely underline many instances of natural enemy HAD. For example, a predator of the gall-forming fly Eurosta solidaginis shows preferences for natal HIPVs relative to non-natal HIPVs [48], which given that $E$. solidaginis exhibits HAD across two Solidago plant species, indicates that divergent HIPVs can underlie sequential radiation of natural enemies.

In addition to plant volatiles, natural enemies can locate prey by eavesdropping on semiochemicals emitted directly from prey, such as pheromones or kairomones (i.e., metabolic byproducts). For example, upon perceiving predation risk, many aphid species emit $(E)-\beta$ farnesene as an alarm pheromone to warn conspecifics, but $(E)-\beta$-farnesene also attracts many species of natural enemies [49]. Herbivore divergence in pheromone emissions following HAD could therefore impact natural enemy foraging, and over time drive sequential radiation of associated natural enemy populations. Upon locating prey through semiochemical detection, prey selection by natural enemies is often driven by prey toxicity [50]. Some herbivores sequester secondary metabolites from host plants for defense against natural enemies, such as Western corn rootworm (Diabrotica virgifera virgifera) larvae sequestering benzoxazinoids for protection from belowground natural enemies [51]. As an herbivore evolves HAD upon colonizing a novel host plant it may sequester novel secondary metabolites that could impact its natural enemies, and lead to sequential radiation.

Importantly, sequential radiation is not always evident, and there are several examples of insect pest HAD that seemingly do not extend to associated parasitoids (Table 1). Currently, all examples of natural enemy HAD follow demonstration of host HAD, but it is important to note that natural enemy HAD may occur in certain systems independently of host HAD [52]. Strong intraspecific competition, for instance, may drive divergence in host use in a given natural enemy species, regardless of HAD in its herbivore host [43]. In such cases, herbivorous pests may benefit from enemy-free space on certain host plant species relative to others, and variation in HIPVs would likely underlie natural enemy divergence in host use. Nevertheless, we focus our review primarily on sequential radiation, or the co-diversification of associated natural enemies as herbivore hosts evolve HAD (Figure 1), as we predict it is likely that natural enemy HAD strongly influences biological control in agroecosystems.

Optimal selection of natural enemies is fundamental for effective biological control in agroecosystems. For example, invasive pest species are often combated through classical biological control, which typically relies on discriminating among a suite of natural enemies originating in the invasive pest's native range, and selectively releasing the most promising natural enemy species in the invaded range. Similarly, conservation and augmentative biological control efforts are enhanced by deliberate selection of natural enemies to conserve or release in agroecosystems. Across all biological control strategies, natural enemy selection often occurs at the species level, and efforts to determine any non-target effects usually focus on interspecies interactions, such as predation or parasitism of non-pest herbivores or predation of other natural enemies, i.e., intraguild predation [53,54]. Within-species variation, in contrast, is often neglected in natural enemy selection, or historically has been restricted to broad-scale geographic or climate-driven variation (e.g., [55]). Although not sequential radiation, an early example illustrates how within-species variation can affect natural enemy foraging preference and biological control outcomes. In the 1930s, a "Japanese race" of the parasitoid Comperiella bifasciata was imported to California for biological control of invasive Yellow scale (Aonidiella citrina) on citrus, and rapidly provided effective control of the scale in southern California [56]. Subsequently, in the 1940s, a "Chinese race" of the parasitoid was introduced to control Yellow scale in the San Joaquin Valley. Soon after, biological control of Yellow scale was achieved, though later it was found that control was due to the "Japanese race," which had been colonized earlier, though reportedly without success. Subsequent field and laboratory studies demonstrated that the "Japanese race" was exclusively parasitic on Yellow scale, while the "Chinese race" was parasitic on California red scale (Aonidiella aurantii) and Yellow scale, but performed better 
and preferred the former host, and became an important component of its biological control in California [56]. Clearly, a better understanding -at the time- of how parasitoid preferences for different host species may vary among distinct parasitoid populations would have ultimately precluded the colonization of the "Chinese" race in the San Joaquin Valley. Thus, the presence of genetically distinct host-associated parasitoid populations may play a key and traditionally overlooked role in biological control, whether classical, conservation, or augmentative strategies are pursued. Here, our main objective is to identify ways in which consideration of HAD may improve natural enemy selection - an enduring, critical issue in biological control, propose broad research directions to further our understanding of chemical cues relevant to HAD and natural enemy selection, and stimulate a discussion concerning the relevance of HAD in biological control.

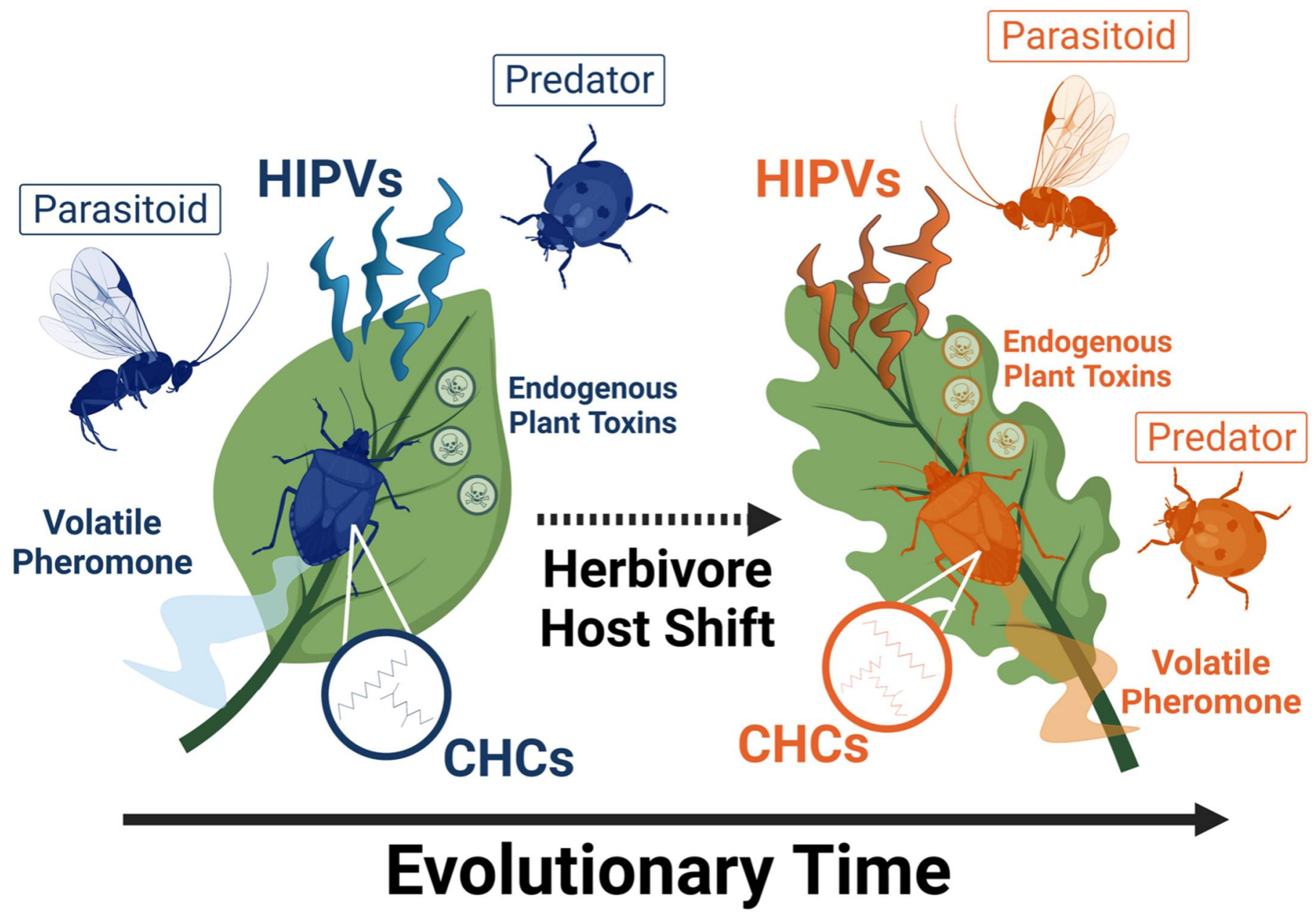

Figure 1. Conceptual model showing one possible evolutionary route to sequential radiation or natural enemy host-associated differentiation (HAD) following herbivore HAD. Populations of herbivores and natural enemies associating with different host-plant species represent genetically divergent populations within the same species of herbivore and natural enemy. HIPVs = herbivoreinduced plant volatiles; $\mathrm{CHCs}=$ cuticular hydrocarbons. Figure generated using BioRender. 
Table 1. Studies testing for sequential radiation in natural enemies, or natural enemy HAD in a single herbivore species which differentially associates with two host-plant species. To be included in this table, quantification of genetic difference between natural enemy populations was required. The genetic signature of HAD typically corresponds to $\mathrm{F}_{\mathrm{ST}} \geq 0.15$ between sympatric, host-associated populations.

\begin{tabular}{|c|c|c|c|c|}
\hline Plant Species & Herbivore Species & Natural Enemy Species & $\begin{array}{l}\text { Natural Enemy HAD } \\
\text { Detected? }\end{array}$ & Source \\
\hline $\begin{array}{c}\text { Alfalfa (Medicago sativa) } \\
\text { Red Clover (Trifolium pratense) }\end{array}$ & $\begin{array}{c}\text { Pea Aphid } \\
\text { (Acyrthosiphon pisum) }\end{array}$ & Parasitoid (Aphidius ervi) & No & [57] \\
\hline $\begin{array}{c}\text { Pecan (Carya illinoinensis) } \\
\text { Water Hickory (Carya aquatica) }\end{array}$ & $\begin{array}{l}\text { Yellow Pecan Aphid } \\
\text { (Monelliopsis pecanis) }\end{array}$ & $\begin{array}{l}\text { Parasitoid (Aphelinus } \\
\text { perpallidus) }\end{array}$ & No & [58] \\
\hline $\begin{array}{l}\text { Almond (Prunus dulcis) } \\
\text { Apricot (Prunus armeniaca) } \\
\text { Peach (Prunus persica) } \\
\text { Plum (Prunus domestica) }\end{array}$ & Aphids (Hyalopterus spp.) & $\begin{array}{l}\text { Parasitoid (Aphidius } \\
\text { transcaspicus) }\end{array}$ & No & [59] \\
\hline $\begin{array}{l}\text { Pinus nigra } \\
\text { Pinus sylvestris }\end{array}$ & $\begin{array}{l}\text { Pine Processionary Moth } \\
\text { (Thaumetopoea pityocampa) }\end{array}$ & $\begin{array}{c}\text { Specialist Parasitoid } \\
\text { (Baryscapus servadeii) } \\
\text { Generalist Parasitoid } \\
\text { (Ooencyrtus pityocampae) }\end{array}$ & No & {$[60]$} \\
\hline $\begin{array}{l}\text { Tall Goldenrod (Solidago } \\
\text { altissima) Giant Goldenrod } \\
\quad \text { (Solidago gigantea) }\end{array}$ & $\begin{array}{c}\text { Gallmakers } \\
\text { (Rhopalomyia solidaginis, } \\
\text { Gnorimoschema } \\
\text { gallaesolidaginis) }\end{array}$ & $\begin{array}{l}\text { Parasitoids } \\
\text { (Platygaster variabilis, } \\
\text { Copidosoma gelechiae) }\end{array}$ & Yes & {$[61]$} \\
\hline $\begin{array}{l}\text { Apples (Malus domestica) } \\
\text { Hawthorns (Crataegus spp.) }\end{array}$ & $\begin{array}{c}\text { Apple Maggot } \\
\text { (Rhagoletis pomonella) }\end{array}$ & $\begin{array}{c}\text { Parasitoids } \\
\text { (Diachasma alloeum, } \\
\text { Utetes canaliculatus, } \\
\text { Diachasmimorpha mellea) }\end{array}$ & Yes & {$[47]$} \\
\hline Yuccas (Yucca spp.) & $\begin{array}{l}\text { Bogus Yucca Moths } \\
\text { (Prodoxus spp.) }\end{array}$ & $\begin{array}{c}\text { Parasitoids } \\
\text { (Eusandalum spp.) }\end{array}$ & No & {$[62]$} \\
\hline Acacia spp. & Thrips (Kladothrips spp.) & $\begin{array}{l}\text { Kleptoparasitic Thrips } \\
\text { (Koptothrips dyskritus, } \\
\text { Koptothrips flavicornis) }\end{array}$ & Yes & {$[43,63]$} \\
\hline
\end{tabular}

\section{Host-Associated Differentiation: Challenges for Biological Control Programs}

\subsection{Classical Biological Control}

Natural enemy selection remains among the most critical issues to resolve for classical biological control. This biocontrol strategy targets invasive pests, and relies on foreign exploration for natural enemies in an invasive pest's native range. These natural enemies are then released into the invaded range, where they become established, and may provide long-term suppression of invasive pest populations. In recent decades, increasing concern for unanticipated ecological impacts of natural enemies released for classical biological control has led to greater scrutiny and deliberate selection of natural enemies for release that pose the least ecological risk, while showing the greatest promise for effective pest suppression [64-66]. While there are numerous examples of classical biological control successes, such as control of cottony cushion scale (Icerya purchasi) with the Vedalia beetle (Novius cardinalis) in California citrus orchards, there are many failed efforts, including a few cases in which non-target effects or ecological impacts have been documented [67-69]. To best safeguard against unwanted effects from natural enemy introduction, a detailed understanding of natural enemy biology and interactions with novel ecological communities is required. For example, introduced natural enemy species may expand their host range upon release in a novel environment, and although this is a problem regardless of natural enemy HAD, the attack of non-target species could lead to the evolution of HAD on newly 
adopted host species. Such host range expansions, especially if they lead to the evolution of HAD on novel hosts, could harm classical biological control efforts if the populations of novel hosts are measurably suppressed or if those species are protected or prized.

When searching for natural enemies in native ranges, incorporating natural enemy HAD into evaluations of candidate species would enhance classical biological control efforts. Traditionally, host species specificity, as well as matching climates between introduced and native ranges, were some of the major criteria used in natural enemy selection [55,70]. While these factors remain important considerations, affirmation that pest species exhibit HAD on different plant species in the native range would necessitate considering whether natural enemies display HAD, i.e., sequential radiation. Such sequential radiation may lead to differential natural enemy preference for HIPVs from different host plants or other host-associated chemical cues. For instance, in the Americas, the generalist pest species, fall armyworm (Spodoptera frugiperda) comprises at least two sympatric and morphologically identical, yet genetically distinct strains, which associate preferentially with different species of host plants [71]. Previous research on a larval parasitoid of fall armyworm detected different host preferences for the two known fall armyworm strains, the Rice and Corn strains [72]. To control fall armyworm populations in specific crops in recently invaded regions, selection of non-corresponding host-associated parasitoids would likely yield diminished classical biological control, although it is important to note that other control methods used in conjunction with biological control would likely improve the management of fall armyworm. Classical biological control of fall armyworm strains highlight how the consideration of herbivore HAD and natural enemy sequential radiation can improve natural enemy selection processes.

Deliberate or unwitting consideration of HAD in invasive pest species, even if HAD is undocumented or unsuspected, may also reduce the frequency of biological control failures. For instance, the "Chinese race" of C. bifasciata plausibly would not have been considered for release against Yellow scale if its preference for- and enhanced performance on California red scale were known in advance (see above). Recently, prior to searching for parasitoids for classical biological control of the mealybug Delottococcus aberiae, an invasive pest of citrus, Beltrà et al. (2015) studied the pest's host affinities [73]. Through integrative taxonomy (i.e., combined morphological and molecular characterization) they uncovered divergent populations of D. aberiae on citrus, wild olive, and Chrysanthemoides monilifera from several South African provinces. They found that the invasive $D$. aberiae populations from Spanish citrus orchards clustered together with populations on citrus from a single South African province, with which they shared COI haplotypes. Based on this result, Beltrà et al. recommended that $D$. aberiae parasitoids be sought specifically on citrus and exclusively in the South African province they identified in their study [73]. Such parasitoids likely respond to citrus HIPVs or other semiochemicals produced by the citrus-associated $D$. aberiae population. Obtaining parasitoids from other D. aberiae populations, such as those associated with wild olive or Chrysanthemoides, would likely result in poorer biological control as these parasitoids would not be adapted to respond to citrus-associated semiochemicals from plants or insect hosts.

Even when considering HAD in herbivore or natural enemy populations, challenges remain when invasive herbivores expand their diet breadth in introduced ranges. Upon introduction into new geographic locations, invasive herbivores often colonize novel host plants [74,75], as seen in the northeastern United States with the brown marmorated stink bug (Halyomorpha halys), and more recently with the spotted lanternfly (Lycorma delicatula). Both species display impressive capacities to feed on wide varieties of host plants, ranging from fruit and vegetable crops in diverse plant families to woody gymnosperms [76,77]. As these invasive herbivores expand their diets, natural enemies introduced from their native ranges may struggle with locating hosts on novel plants [78], reducing biological control effectiveness. One possible explanation is that novel host plants may not perceive invasive insect herbivory, instead responding only to mechanical wounding and not emitting the particular HIPVs essential for effective natural enemy foraging [78]. Disruption of host- 
associated chemical cues could reduce classical biological control efforts. Rapid expansion in diet breadth indicates that invasive herbivores may outpace natural enemies in HAD as they move to novel plants and evade natural enemy attack. Fall armyworm, which has numerous hosts across many plant families [79], may illustrate this case as it continues to spread across continents and encounters novel hosts. Overall, however, very few empirical studies to date have characterized HIPVs following invasive insect herbivory, which is a critical gap in our knowledge and could contribute to our understanding of natural enemy sequential radiation.

Evolutionary or breeding history of novel crop hosts is also important to consider when invasive herbivores expand their diet breadth. In the case of fall armyworm, maizethe most affected crop in invaded regions of Africa and Asia-had not been exposed to fall armyworm for hundreds of crop and insect generations, so its HIPV emissions, as well as other defensive responses, may have been lost or weakened. In this way, fall armyworm associations with maize in Africa and Asia could be considered 'novel.' Recently, one study showed that North American maize breeding lines did not emit the HIPV (E)- $\beta$ caryophyllene, known to be emitted in response to leaf-feeding by Spodoptera littoralis, and root-feeding by Western corn rootworm [80]. The same study showed that the gene responsible for the HIPV's emission, TPS23, is maintained by positive selection in European maize and its wild ancestor, but is largely inactive in most North American lines, which do not emit the HIPV. The combined results of that study and a recent study [Bernal et al. unpublished] suggest that $(E)$ - $\beta$-caryophyllene signaling was lost during the breeding of North American maize lines in the last $\sim 100$ years. The loss of $(E)$ - $\beta$-caryophyllene has been shown to disrupt attraction of insect-killing nematodes to Western corn rootworm-infested roots, and likely also disrupts natural enemy attraction to fall armyworm feeding on such lines. Variation in HIPV emissions within plant species highlights another important source of variation that can influence natural enemy attraction to host plants and ultimately shape natural enemy HAD.

In addition to HIPVs, some species of natural enemies can detect prey pheromones and use pheromone emissions to locate prey when foraging. Natural enemies can respond to prey sex pheromones, as is the case for Elater ferrugineus, the predator of the scarab beetle Osmoderma eremita [81]. Prey aggregation pheromones also attract natural enemies of thrips (Frankliniella occidentalis) [82], stink bugs (Thyanta pallidovirens) [83], and bark beetles (Ips spp. and Dryophthorus americanus) [84]. In some instances, the chemical blend of prey pheromone emissions can diverge within a species and produce unique 'pheromone strains' of pestiferous herbivores [85]. For example, the European corn borer (Ostrinia nubilalis), a major pest of maize worldwide, consists of two distinct strains in which females produce different sex pheromones, driving assortative mating within each population [86]. Studies of European corn borer host-plant associations in France revealed that the different strains preferentially colonized different host plants, suggesting that HAD could play a role in maintaining the distinct strains [86]. The divergent pheromone blends or host-plant associations may drive natural enemy HAD in the European corn borer system, but this remains unknown. Intriguingly, a tachinid parasitoid (Trichopoda pennipes) is attracted to green stink bug (Nezara viridula) aggregation pheromone, and pheromone strains of green stink bug were identified from a failed biological control effort with this natural enemy [87]. An introduction of this parasitoid species from the southern United States to Hawaii resulted in no parasitism of green stink bugs [88], and further investigations revealed divergent pheromone blends between the two stink bug populations [89]. Although these differences were likely driven by geographic isolation rather than green stink bug HAD, the impacts on natural enemy foraging efficiency highlight how changes in chemical cues can disrupt biological control.

Contact pheromones, or cuticular hydrocarbons (CHCs), also mediate within-species recognition among insects. CHCs are primarily made up of various long-chain waxes, such as alkanes and alkenes, and are perceived by physical contact between individual insects and provide relevant information about the identity of a species [90]. The composition 
of CHCs for herbivores is dictated in large part by diet, as ingested host-plant lipids, proteins, and carbohydrates provide the basis for biosynthesis of CHCs [91]. Intraspecific variation in $\mathrm{CHC}$ profiles can occur when individuals from a given herbivore species feed on different host-plant species [92,93]. Host-plant-induced variations in CHCs can drive mating preferences for individuals sharing the same host plant and ultimately result in assortative mating within populations [94], suggesting CHCs play an important mechanistic role in the beginning stages of HAD. For example, $\mathrm{CHC}$ profiles of mustard leaf beetles (Phaedon cochleariae) vary depending on host-plant species use, and these changes in CHCs determine mating preferences, as individuals prefer to mate with other individuals from the same rather than different host plants [95-97]. Some natural enemy species, such as parasitoids, also rely on CHCs to identify their host species for oviposition $[98,99]$. Although only one study to date has connected prey HAD to changes in CHCs [100], we postulate that this is likely a common scenario, and the extent to which CHCs diverge within prey populations could determine whether natural enemy HAD will also occur. Divergent pheromone emissions could play roles in natural enemy HAD and efficacy, which should be considered in efforts for natural enemy encouragement in classical biological control.

\subsection{Conservation Biological Control}

Conservation biological control utilizes natural enemy populations already present in agroecological landscapes to suppress pests on crops, increasing the abundance of natural enemies and enhancing the impact of biological control on pest populations [101]. Accomplishing pest suppression using this strategy typically involves habitat manipulation within agricultural fields or surrounding areas. For instance, cover crops, intercropping, and planting floral borders all enhance structural complexity and increase levels of nutritional resources necessary for natural enemy foraging and survival [102]. In addition to habitat manipulation, manipulation of chemical cues to enhance natural enemy attraction to agricultural fields is another conservation biological control tactic that shows promise $[103,104]$. Many natural enemies show strong attraction to the same HIPVs, such as methyl salicylate, and efforts to deploy synthetic methyl salicylate lures have yielded generally positive results in agricultural fields by enhancing natural enemy recruitment and arrest [105]. Despite advances in habitat and chemical manipulation to enhance conservation biological control, much work remains in furthering the use and efficacy of conservation biological control. The chemical ecology of natural enemy HAD may play an overlooked role in advancing conservation biological control practices.

Although conservation biological control can contribute to suppression of invasive pests, this biocontrol strategy is most important for native pests as natural enemies are presumed to be adapted to pests with which they have been long associated over novel hosts or prey, such as invasive pests. Extensive co-evolutionary relationships in native ranges between natural enemies and prey results in closely adapted natural enemy communities [106], which readily detect and respond to chemical cues from herbivores and their infested plants. Non-native host plants, such as introduced crops, however, could impact conservation biological control if native pests expand their diet breadth to introduced hosts. Agricultural crops are a recurring type of non-native plant, as crops are often grown throughout the world in areas far from their regions of origin [107]. As such, any colonization event by an herbivore in its native range to an introduced crop represents a novel, non-co-evolved interaction. For example, two species of pestiferous, stem boring moths (Diatraea spp.) are co-evolved with maize but host-shifted to introduced agricultural crops of the maize (Poaceae) family—sugarcane, sorghum, and rice-, and genetically distinct populations of the moths were shown to attack each crop species [108]. Further, investigations into associated parasitoids revealed low levels of parasitism in the introduced crops relative to maize, particularly for one of the moth species [108]. A plausible explanation was that introduced crops did not produce attractive HIPVs for native natural enemies, creating "enemy-free space" for the stemborers, which allowed them to effectively hide from their associated predators or parasitoids. Pest HAD with novel crops could serve 
as a mechanism for pest emergence, and stymie conservation biological control efforts at their outset.

Beyond introduced crops, native pests can also colonize introduced or invasive noncrop species with the potential for HAD to develop over time and alter conservation biological control [109]. Host range expansions to novel plants can provide "enemy-free space" for herbivores and thereby increase their survival and population sizes. For instance, in the presence of predators, the Alaskan swallowtail butterfly (Papilio machaon aliaska) adopted novel hosts on which larval survival increased relative to ancestral hosts [110]. However, when predators were removed from the system, this effect was reversed and larval survival was lower on novel hosts than ancestral hosts, suggesting novel hosts are lower quality but offer greater protection from natural enemies than ancestral hosts [110]. These findings underscore how the incorporation of a novel host into the diet breadth of a native herbivore may disrupt conservation biological control. Unfamiliar host-associated chemical cues likely underlie natural enemy avoidance or the non-detection of native prey on novel hosts. For example, the non-detection of native prey on novel hosts may occur if novel host plants do not emit HIPVs that are attractive to native natural enemies. Recent evidence from ragwort (Jacobaea vulgaris) plants found that native populations emitted high levels of HIPVs and readily attracted native natural enemies, whereas invasive ragwort populations produced lower levels of HIPVs [111]. The same species of natural enemies are not present in the invasive range of ragwort, leading invasive ragwort populations to reduce investment in HIPV emissions [111]. In the context of the invaded ecological community, invasive plants offer native herbivores the opportunity to avoid detection by their co-evolved natural enemies through reduced HIPV emissions. Avoidance of natural enemies may promote native herbivore host shifts to novel host plants [112]. Relatedly, native herbivores may sequester secondary metabolites from novel plants and increase or decrease their toxicity to native natural enemies $[113,114]$. Such changes in prey toxicity can cascade to help or hinder natural enemy attack or development within hosts $[115,116]$. For instance, the performance of a native parasitoid species (Cotesia glomerata) was reduced when completing development in herbivores feeding on a novel crucifer species relative to native Brassica nigra [117], and it is possible that differences in secondary metabolite sequestration by native herbivores underlie differences in natural enemy performance [109]. If herbivore toxicity to natural enemies increases when herbivores feed on novel hosts, this could favor herbivore HAD, if sufficient evolutionary time elapsed and survival increased on novel host plants in the presence of natural enemies. Regardless of the mechanism, native herbivore HAD on novel, introduced or invasive host plants can hamper conservation biological control.

Invasive insect herbivores are generally not the targets of conservation biological control. However, how invasive herbivores interact with native ecological communities can determine the outcomes of chemically mediated predator-prey interactions and conservation biological control. For instance, cabbage white (Pieris brassicae) herbivory on its native host plant (Brassica rapa) induces HIPVs that recruit the braconid wasp parasitoid C. glomerata, but this recruitment stops when plants are dually attacked by both cabbage whites and an exotic herbivore, Spodoptera littoralis [118]. Similarly, when an invasive brown marmorated stink bug concurrently attacks plants with native herbivores, the natural enemy attraction to native HIPVs is attenuated [119]. Thus, invasive herbivores can have far-reaching effects in ecological communities, ultimately interfering with conservation biological control through disrupted HIPV recruitment of natural enemies [120]. To date, most research on HAD and sequential radiation has focused on pairwise interactions between herbivores and their associated natural enemies, neglecting the role of other members of the ecological community in disrupting chemical cues used for host location. Expanding our view of HAD to entire ecological communities will likely shape our understanding of the factors driving the development of sequential radiation [121]. Further explorations into how invasive species mediate interactions between natural enemies and their herbi- 
vore hosts, particularly in the context of sequential radiation, will enhance conservation biological control.

\subsection{Augmentative Biological Control}

In the case of augmentative biological control, which utilizes natural enemies reproduced in laboratories or industrial facilities for release against pests, HAD may be most important in rearing facilities, in reference to both natural enemy and host or prey species. Rearing environments are divergent from natural and agricultural habitats, particularly because they typically are designed to enhance production (quantity or volume) over quality [122]. In artificial rearing environments, competition is managed and limited to intraspecific competition, hosts or prey for natural enemies and food for hosts or prey are readily available, and all other environmental variables are optimized for natural enemy or host survival and reproduction. Thus, the selective pressures in these environments drastically differ from those in natural or agricultural habitats, and select for adaptation to rearing environments; as importantly, genetic drift and inbreeding may also affect mass-reared natural enemy and host population [123-125], and contribute to the evolution of HAD. For example, because of selection, drift, or inbreeding, natural enemies may become adapted to laboratory-adapted hosts that differ from field populations of hosts, and such adaptation may lead to natural enemy HAD in the rearing environment, and biological control failures in the field [126]. Similarly, natural enemy HAD may evolve when natural enemies are reared on factitious hosts (i.e., different from the targeted pest) because these can be reared more economically than the targeted pest. Overall, natural enemy HAD on the rearing host can reduce efficacy of biological control in the field, as was demonstrated for the specialist egg parasitoid Trichogramma galloi [127]. Rearing this parasitoid for numerous generations on a factitious host resulted in lower parasitoid fitness when reintroduced to the natural, pestiferous host [127], suggesting natural enemy HAD on the factitious host. Similar reductions in natural enemy efficacy following rearing on a factitious host were also observed for natural enemies of boll weevils (Anthonomus grandis) [128] and pea aphids [129]. Rearing environments also remove many of the chemical cues used in host location for natural enemies, such as HIPVs, which could result in natural enemy populations that are less responsive to such chemical cues. When rearing natural enemies for augmentative biological control, one possible way to overcome HAD is to frequently introduce natural enemies and hosts from the field to avoid evolution of natural enemy HAD on factitious hosts, and host adaptation to rearing environments [123,125].

\section{Future Directions}

We predict natural enemy and pest HAD influence biological control outcomes under many scenarios. Differential detection of host-associated chemical cues across host populations likely drives natural enemy HAD. Chemical cues derived from plants (e.g., HIPVs) and directly from herbivores (e.g., pheromones) can influence natural enemy foraging and host location, but these chemical cues can change following herbivore HAD. Such changes can cascade to shape herbivore interactions with their associated natural enemies, and possibly even drive sequential radiation. To date, relatively few cases of sequential radiation have been documented, and so far, tests for natural enemy HAD have only been conducted for parasitoids and not for other types of natural enemies, such as predators (Table 1), which could reflect a number of non-mutually exclusive scenarios. First, generalist natural enemies may easily exploit different host species. Relying on a general suite of different hosts rather than one particular host species would likely minimize assortative mating and thereby slow the evolution of natural enemy HAD. Second, during their lifetimes, natural enemies often exhibit phenotypic plasticity in learning. Learning may enhance natural enemy responsiveness to host-associated cues. If natural enemies quickly learn, this could dampen the development of natural enemy HAD, as innate preferences for different hosts would not easily be maintained in such natural enemy populations. Third, it is also possible that natural enemy host-associated populations or host-races are 
short-lived, evolving relatively quickly into separate species, and reducing the chances of finding true host-races at any given point in time, although this scenario remains difficult to experimentally test. Fourth, natural enemies may not keep up with herbivores as they adopt novel host plants, preventing sequential radiation. To conclusively determine the relevance of any of these scenarios to the evolution of natural enemy HAD, future research should focus on examining natural enemy HAD across more crop-, pest-, and natural enemy associations.

Addressing whether and how frequently natural enemy HAD occurs will improve the predictability of biological control outcomes, whether classical, conservation, or augmentative biological control is pursued. Pest HAD is predicted to occur in endophagous insects with reduced genetic recombination, but there is currently no consensus concerning which natural enemy lifestyles lead more frequently to HAD [23]. Extrapolating from pest HAD predictions, endoparasitoids, particularly those showing haplodiploidy, for example, may be more prone to natural enemy HAD than generalist predators that reproduce sexually, but this has not been explicitly tested. However, some studies show how drift, inbreeding, and selection affect natural enemies in biological control, particularly parasitoids given their haplodiploidy $[123,125,130]$. Notably, there are examples of HAD that defy theoretical predictions, such as HAD in sexually reproducing species [131], and predators that prefer different host-associated herbivore populations-although the degree of genetic divergence in this natural enemy species has not been elucidated and thereby cannot yet be considered HAD [132]. Without more empirical evidence, it is difficult to make strong predictions, so further investigation into natural enemy HAD across different systems is warranted.

Breeding natural enemies is one way to combat the challenges of HAD in natural enemy selection. Breeding or artificial selection harnesses genetic variation within natural enemy populations to enhance pest suppression and improve biological control [133]. However, identifying natural enemy traits relevant to biological control effectiveness, and with sufficient heritable genetic variation, remains challenging. A number of traits have been proposed, and one of increasing interest is natural enemy learning behavior [133]. Since natural enemies exhibit an impressive capacity to learn and respond to chemical stimuli, natural enemy populations could be artificially selected over many generations for enhanced response to select chemical cues [134]. Such chemical cues would correspond to host-associated herbivores and include plant- or herbivore-derived cues [135]. For instance, the entomopathogenic nematode, Heterorhabditis bacteriophora, attacks soil-dwelling insect herbivores, such as the major maize pest, Western corn rootworm. Following belowground rootworm herbivory, maize roots emit $(E)$ - $\beta$-caryophyllene [136], and this HIPV recruits $H$. bacteriophora to kill rootworms [137]. Previous efforts to employ selective breeding strategies for $H$. bacteriophora increased its responsiveness to $(E)-\beta$-caryophyllene after only six generations and also enhanced control of rootworms in the field [138]. Employing similar strategies to produce populations of different natural enemies can help to overcome the limitations of biological control for pests exhibiting HAD.

Currently, knowledge of natural enemy HAD extends only to insect predators, parasitoids, or entomopathogenic nematodes. However, microbial entomopathogens are increasingly utilized as biological control agents against insect pests, but it is unknown whether HAD occurs in these entomopathogens. Investigation into a common fungal entomopathogen, Beauveria bassiana, revealed no intraspecific genetic variation across 36 different B. bassiana strains [139], but it remains unclear if this extends to other species of fungal entomopathogens. Recent research demonstrated sequential radiation between species of tree, beetle, and mutualistic fungal symbiont [140], suggesting a capacity for fungal entomopathogens to also exhibit HAD. Bacterial symbionts or even entire hostassociated microbiota can contribute to HAD [141-144], suggesting a capacity for bacterial entomopathogens to show HAD. The most important bacterial entomopathogen for biological control in agroecosystems is Bacillus thuringiensis, or 'Bt.' Different subspecies of Bt are utilized to control different types of insects, such as Bacillus thuringiensis israelensis for mosquito management or Bacillus thuringiensis kurstaki for managing lepidopteran 
pests, further implying bacterial entomopathogens likely possess the capability to express HAD. Determining the extent of HAD in microbial entomopathogens will improve natural enemy selection.

A final recommendation for future research is to consider pest HAD in the context of pest immune response to biological control agents. Insects deploy immune responses to fend off different types of natural enemies [145]. One common immune strategy against attack from endoparasitoids is encapsulation, often by hemocytes that surround and suffocate parasitoid eggs or young larvae, preventing the development of parasitoids within their host's body [146]. Encapsulation abilities can vary within species, producing pest strains that are resistant or susceptible to parasitoid attack, as is the case for different strains of Drosophila melanogaster attacked by the parasitoid, Leptopilina boulardi [147]. Beyond exploiting different host plant species, pests exhibiting HAD may also differ in their immune responses to natural enemies, likely as a result of evolutionary forces (e.g., genetic drift, mutation, selection) acting in unique ways within each host-associated population. In contrast, natural enemies can also show different intraspecific responses to host immune systems. Evidence from recent work with the pestiferous maize stalk borer, Busseola fusca, in Africa indicated different subpopulations of a parasitoid species were differentially susceptible to maize stalk borer defenses: one subpopulation evaded host immunity, while another was encapsulated [148]. Natural enemy populations varying in susceptibility to pest immune responses could exacerbate sequential radiation and natural enemy HAD as different natural enemy populations evolve in concert with host-associated prey. Incorporating pest immune responses, particularly in species with already-determined HAD, will likely be important in furthering biological control efforts.

\section{Conclusions}

We conclude that chemical cues underlying HAD are powerful drivers of interactions between host plants, pests, and their associated natural enemies. To improve selection and use of natural enemies in agroecosystems, future work must consider pest and natural enemy HAD, with emphasis on chemical communication among crop plants, pests, and natural enemies. Incorporating investigations into the chemical cues mediating these interactions provides mechanistic links between pest and natural enemy HAD, and offers innovative opportunities to improve natural enemy selection in biological control and manipulate agrochemical ecology to enhance biological control.

Author Contributions: Conceptualization, M.N.T.; writing—original draft preparation, M.N.T.; writing-review and editing, M.N.T., R.F.M., A.M.H., and J.S.B.; visualization, M.N.T.; supervision, J.S.B.; funding acquisition, M.N.T., R.F.M., A.M.H., and J.S.B. All authors have read and agreed to the published version of the manuscript.

Funding: This manuscript was funded in part by a Texas A\&M University College of Agriculture \& Life Sciences Merit Fellowship and a John A. Jackman Endowed Scholarship (to M.N.T.) and HATCH projects TEX0-1-9066 (to A.M.H.), TEX09185 (to R.F.M.), and TEX07234 (to J.S.B.).

Institutional Review Board Statement: Not applicable.

Data Availability Statement: Not applicable.

Acknowledgments: We thank the three anonymous reviewers and Aggie Women in Entomology (AWE) Writing Group for helpful feedback on earlier drafts of this manuscript.

Conflicts of Interest: The authors declare no conflict of interest.

\section{References}

1. Losos, J.B.; Mahler, D.L. Adaptive radiation: The interaction of ecological opportunity, adaptation, and speciation. In Evolution since Darwin: The First 150 Years; Sinauer Associates: Sunderland, MA, USA, 2010; pp. 381-420.

2. Stroud, J.T.; Losos, J.B. Ecological opportunity and adaptive radiation. Annu. Rev. Ecol. Evol. Syst. 2016, 47, 507-532. [CrossRef]

3. Brodersen, J.; Post, D.M.; Seehausen, O. Upward adaptive radiation cascades: Predator diversification induced by prey diversification. Trends Ecol. Evol. 2018, 33, 59-70. [CrossRef] [PubMed] 
4. Zuzarte-Luís, V.; Mota, M.M. Parasite sensing of host nutrients and environmental cues. Cell Host Microbe 2018, 23, 749-758. [CrossRef] [PubMed]

5. Schmid-Hempel, P. Evolutionary Parasitology: The Integrated Study of Infections, Immunology, Ecology, and Genetics; Oxford University Press: Oxford, UK, 2021.

6. Vinson, S.B. How parasitoids deal with the immune system of their host: An overview. Arch. Insect Biochem. Physiol. 1990, 13, 3-27. [CrossRef]

7. Brodeur, J. Host specificity in biological control: Insights from opportunistic pathogens. Evol. Appl. 2012, 5, 470-480. [CrossRef] [PubMed]

8. Vorburger, C. Defensive symbionts and the evolution of parasitoid host specialization. Annu. Rev. Entomol. 2022, 67, 329-346. [CrossRef]

9. Jaenike, J. Host specialization in phytophagous insects. Annu. Rev. Ecol. Syst. 1990, 21, 243-273. [CrossRef]

10. Barrett, L.G.; Heil, M. Unifying concepts and mechanisms in the specificity of plant-enemy interactions. Trends Plant Sci. 2012, 17, 282-292. [CrossRef] [PubMed]

11. Forister, M.L.; Dyer, L.A.; Singer, M.S.; Stireman, J.O., III; Lill, J.T. Revisiting the evolution of ecological specialization, with emphasis on insect-plant interactions. Ecology 2012, 93, 981-991. [CrossRef] [PubMed]

12. Hardy, N.B.; Kaczvinsky, C.; Bird, G.; Normark, B.B. What we don't know about diet-breadth evolution in herbivorous insects Annu. Rev. Ecol. Evol. Syst. 2020, 51, 103-122. [CrossRef]

13. Rashid War, A.; Kumar Taggar, G.; Hussain, B.; Sachdeva Taggar, M.; Nair, R.M.; Sharma, H.C. Plant defense against herbivory and insect adaptations. AoB Plants 2018, 10, ply037. [CrossRef]

14. Webster, B.; Cardé, R.T. Use of habitat odour by host-seeking insects: Use of habitat odour by host-seeking insects. Biol. Rev. 2017, 92, 1241-1249. [CrossRef] [PubMed]

15. Godfray, H.C.J.; Godfray, H. Parasitoids: Behavioral and Evolutionary Ecology; Princeton University Press: Princeton, NJ, USA, 1994.

16. Agosta, S.J. On ecological fitting, plant-insect associations, herbivore host shifts, and host plant selection. Oikos 2006, 114, 556-565. [CrossRef]

17. Vosteen, I.; Gershenzon, J.; Kunert, G. Enemy-free space promotes maintenance of host races in an aphid species. Oecologia 2016, 181, 659-672. [CrossRef] [PubMed]

18. Feder, J.L.; Reynolds, K.; Go, W.; Wang, E.C. Intra-and interspecific competition and host race formation in the apple maggot fly, Rhagoletis pomonella (Diptera: Tephritidae). Oecologia 1995, 101, 416-425. [CrossRef] [PubMed]

19. Ragland, G.J.; Sim, S.B.; Goudarzi, S.; Feder, J.L.; Hahn, D.A. Environmental interactions during host race formation: Host fruit environment moderates a seasonal shift in phenology in host races of Rhagoletis pomonella. Funct. Ecol. 2012, 26, 921-931. [CrossRef]

20. Berlocher, S.H.; Feder, J.L. Sympatric speciation in phytophagous insects: Moving beyond controversy? Annu. Rev. Entomol. 2002, 47, 773-815. [CrossRef]

21. Stireman, J.O., III; Nason, J.D.; Heard, S.B. Host-associated genetic differentiation in phytophagous insects: General phenomenon or isolated exceptions? Evidence from a goldenrod-insect community. Evolution 2005, 59, 2573-2587. [CrossRef]

22. Harrison, K.; Tarone, A.M.; DeWitt, T.; Medina, R.F. Predicting the occurrence of host-associated differentiation in parasitic arthropods: A quantitative literature review. Entomol. Exp. Appl. 2022, 170, 5-22. [CrossRef]

23. Medina, R.F. Implications of host-associated differentiation in the control of pest species. In Insect Outbreaks Revisited; John Wiley \& Sons: Hoboken, NJ, USA, 2012; pp. 291-310.

24. Carroll, S.P.; Boyd, C. Host race radiation in the soapberry bug: Natural history with the history. Evolution 1992, 46, 1052-1069. [CrossRef]

25. Segar, S.T.; Volf, M.; Sisol, M.; Pardikes, N.A.; Souto-Vilarós, D. Chemical cues and genetic divergence in insects on plants: Conceptual cross pollination between mutualistic and antagonistic systems. Curr. Opin. Insect Sci. 2019, 32, 83-90. [CrossRef] [PubMed]

26. Forbes, A.A.; Devine, S.N.; Hippee, A.C.; Tvedte, E.S.; Ward, A.K.G.; Widmayer, H.A.; Wilson, C.J. Revisiting the particular role of host shifts in initiating insect speciation: Perspective. Evolution 2017, 71, 1126-1137. [CrossRef] [PubMed]

27. Jean, P.; Jean-Christophe, S. The pea aphid complex as a model of ecological speciation. Ecol. Entomol. 2010, 35, 30. [CrossRef]

28. Via, S. Reproductive isolation between sympatric races of pea aphids. i. gene flow restriction and habitat choice. Evolution 1999, 53, 1446-1457. [CrossRef] [PubMed]

29. Caillaud, M.C.; Via, S. Specialized feeding behavior influences both ecological specialization and assortative mating in sympatric host races of pea aphids. Am. Nat. 2000, 156, 606-621. [CrossRef] [PubMed]

30. Hawthorne, D.J.; Via, S. Genetic linkage of ecological specialization and reproductive isolation in pea aphids. Nature 2001, 412, 904-907. [CrossRef]

31. Hood, G.R.; Zhang, L.; Hu, E.G.; Ott, J.R.; Egan, S.P. Cascading reproductive isolation: Plant phenology drives temporal isolation among populations of a host-specific herbivore. Evolution 2019, 73, 554-568. [CrossRef] [PubMed]

32. Bernal, J.S.; Medina, R.F. Agriculture sows pests: How crop domestication, host shifts, and agricultural intensification can create insect pests from herbivores. Curr. Opin. Insect Sci. 2018, 26, 76-81. [CrossRef]

33. Feder, J.L.; Opp, S.B.; Wlazlo, B.; Reynolds, K.; Go, W.; Spisak, S. Host fidelity is an effective premating barrier between sympatric races of the apple maggot fly. Proc. Natl. Acad. Sci. USA 1994, 91, 7990-7994. [CrossRef] 
34. Stelinski, L.; Liburd, O. Behavioral evidence for host fidelity among populations of the parasitic wasp, Diachasma alloeum (Muesebeck). Naturwissenschaften 2005, 92, 65-68. [CrossRef]

35. Pureswaran, D.S.; Hofstetter, R.W.; Sullivan, B.T.; Grady, A.M.; Brownie, C. Western pine beetle populations in Arizona and California differ in the composition of their aggregation pheromones. J. Chem. Ecol. 2016, 42, 404-413. [CrossRef] [PubMed]

36. Groot, A.T.; Marr, M.; Schöfl, G.; Lorenz, S.; Svatos, A.; Heckel, D.G. Host strain specific sex pheromone variation in Spodoptera frugiperda. Front. Zool. 2008, 5, 20. [CrossRef] [PubMed]

37. Marmolejo, L.O.; Thompson, M.N.; Helms, A.M. Defense suppression through interplant communication depends on the attacking herbivore species. J. Chem. Ecol. 2021, 47, 1049-1061. [CrossRef] [PubMed]

38. De Moraes, C.M.; Mescher, M.C.; Tumlinson, J.H. Caterpillar-induced nocturnal plant volatiles repel conspecific females. Nature 2001, 410, 577-580. [CrossRef] [PubMed]

39. Robert, C.A.M.; Erb, M.; Duployer, M.; Zwahlen, C.; Doyen, G.R.; Turlings, T.C.J. Herbivore-induced plant volatiles mediate host selection by a root herbivore. New Phytol. 2012, 194, 1061-1069. [CrossRef] [PubMed]

40. Grunseich, J.M.; Thompson, M.N.; Hay, A.A.; Gorman, Z.; Kolomiets, M.V.; Eubanks, M.D.; Helms, A.M. Risky roots and careful herbivores: Sustained herbivory by a root-feeding herbivore attenuates indirect plant defences. Funct. Ecol. 2020, 34, 1779-1789. [CrossRef]

41. Del Campo, M.; Via, S.; Caillaud, M.C. Recognition of host-specific chemical stimulants in two sympatric host races of the pea aphid Acyrthosiphon pisum. Ecol. Entomol. 2003, 28, 405-412. [CrossRef]

42. Oroño, L.; Paulin, L.; Alberti, A.C.; Hilal, M.; Ovruski, S.; Vilardi, J.C.; Rull, J.; Aluja, M. Effect of host plant chemistry on genetic differentiation and reduction of gene flow among Anastrepha fraterculus (Diptera: Tephritidae) populations exploiting sympatric, synchronic hosts. Environ. Entomol. 2013, 42, 790-798. [CrossRef]

43. Blair, C.; Abrahamson, W. Sequential radiation through host-race formation: Herbivore diversity leads to diversity in natural enemies. In Specialization, Speciation, and Radiation: The Evolutionary Biology of Herbivorous Insects; University of California Press: Oakland, CA, USA, 2008; pp. 188-200.

44. Forbes, A.A.; Powell, T.H.; Stelinski, L.L.; Smith, J.J.; Feder, J.L. Sequential sympatric speciation across trophic levels. Science 2009, 323, 776-779. [CrossRef]

45. Rull, J.; Wharton, R.; Feder, J.L.; Guillén, L.; Sivinski, J.; Forbes, A.; Aluja, M. Latitudinal variation in parasitoid guild composition and parasitism rates of North American hawthorn infesting Rhagoletis. Environ. Entomol. 2009, 38, 588-599. [CrossRef]

46. Feder, J.L.; Forbes, A.A. Sequential speciation and the diversity of parasitic insects. Ecol. Entomol. 2010, 35, 67-76. [CrossRef]

47. Hood, G.R.; Forbes, A.A.; Powell, T.H.Q.; Egan, S.P.; Hamerlinck, G.; Smith, J.J.; Feder, J.L. Sequential divergence and the multiplicative origin of community diversity. Proc. Natl. Acad. Sci. USA 2015, 112, E5980-E5989. [CrossRef] [PubMed]

48. Rhodes, B.C.; Blair, C.P.; Takahashi, M.K.; Abrahamson, W.G. The role of olfactory cues in the sequential radiation of a gall boring beetle, Mordellistena convicta. Ecol. Entomol. 2012, 37, 500-507. [CrossRef]

49. Joachim, C.; Weisser, W.W. Does the aphid alarm pheromone (E)- $\beta$-farnesene act as a kairomone under field conditions? J. Chem. Ecol. 2015, 41, 267-275. [CrossRef]

50. Zvereva, E.L.; Kozlov, M.V. The costs and effectiveness of chemical defenses in herbivorous insects: A meta-analysis. Ecol. Monogr. 2015, 86, 107-124. [CrossRef]

51. Bruno, P.; Machado, R.A.R.; Glauser, G.; Köhler, A.; Campos-Herrera, R.; Bernal, J.; Toepfer, S.; Erb, M.; Robert, C.A.; Arce, C.C.; et al. Entomopathogenic nematodes from Mexico that can overcome the resistance mechanisms of the western corn rootworm. Sci. Rep. 2020, 10, 8257. [CrossRef]

52. Cronin, J.T.; Abrahamson, W.G. Do parasitoids diversify in response to host-plant shifts by herbivorous insects? Ecol. Entomol. 2001, 26, 347-355. [CrossRef]

53. Rosenheim, J.A.; Kaya, H.K.; Ehler, L.E.; Marois, J.J.; Jaffee, B.A. Intraguild predation among biological-control agents: Theory and evidence. Biol. Control 1995, 5, 303-335. [CrossRef]

54. Follett, P.A.; Duan, J.J. Nontarget Effects of Biological Control; Springer Science \& Business Media: Boston, MA, USA, 2012.

55. Messenger, P.; Van den Bosch, R. The adaptability of introduced biological control agents. In Biological Control; Springer: Boston, MA, USA, 1971; pp. 68-92.

56. Rosen, D.; DeBach, P. Diaspididae. In Introduced Parasites and Predators of Arthropod Pests and Weeds: A World Review; Agricultural Research Service: Washington, DC, USA, 1978; p. 78.

57. Bilodeau, E.; Simon, J.-C.; Guay, J.-F.; Turgeon, J.; Cloutier, C. Does variation in host plant association and symbiont infection of pea aphid populations induce genetic and behaviour differentiation of its main parasitoid, Aphidius ervi? Evol. Ecol. 2013, 27, 165-184. [CrossRef]

58. Dickey, A.M.; Medina, R.F. Lack of sequential radiation in a parasitoid of a host-associated aphid: No sequential radiation in aphid parasitoid. Entomol. Exp. Appl. 2011, 139, 154-160. [CrossRef]

59. Lozier, J.D.; Roderick, G.K.; Mills, N.J. Molecular markers reveal strong geographic, but not host associated, genetic differentiation in Aphidius transcaspicus, a parasitoid of the aphid genus Hyalopterus. Bull. Entomol. Res. 2009, 99, 83-96. [CrossRef] [PubMed]

60. Simonato, M.; Battisti, A.; Zovi, D.; Medina, R.F. Testing for host-associated differentiation in two egg parasitoids of a forest herbivore. Entomol. Exp. Appl. 2012, 145, 124-133. [CrossRef]

61. Stireman, J.O.; Nason, J.D.; Heard, S.B.; Seehawer, J.M. Cascading host-associated genetic differentiation in parasitoids of phytophagous insects. Proc. R. Soc. B 2006, 273, 523-530. [CrossRef] [PubMed] 
62. Althoff, D.M. A test of host-associated differentiation across the 'parasite continuum' in the tri-trophic interaction among yuccas, bogus yucca moths, and parasitoids. Mol. Ecol. 2008, 17, 3917-3927. [CrossRef] [PubMed]

63. Crespi, B.; Abbot, P. The behavioral ecology and evolution of kleptoparasitism in Australian gall thrips. Fla. Entomol. 1999, 82, 147-164. [CrossRef]

64. Barratt, B.; Howarth, F.; Withers, T.; Kean, J.; Ridley, G. Progress in risk assessment for classical biological control. Biol. Control 2010, 52, 245-254. [CrossRef]

65. Van Driesche, R.; Carruthers, R.; Center, T.; Hoddle, M.; Hough-Goldstein, J.; Morin, L.; Smith, L.; Wagner, D.L.; Blossey, B.; Brancatini, V.; et al. Classical biological control for the protection of natural ecosystems. Biol. Control 2010, 54, S2-S33. [CrossRef]

66. Messing, R.; Brodeur, J. Current challenges to the implementation of classical biological control. BioControl 2018, 63, 1-9. [CrossRef]

67. Hoddle, M.S. Restoring balance: Using exotic species to control invasive exotic species. Conserv. Biol. 2004, 18, 38-49. [CrossRef]

68. Messing, R.H.; Wright, M.G. Biological control of invasive species: Solution or pollution? Front. Ecol. Environ. 2006, 4, 132-140. [CrossRef]

69. Pearson, D.E.; Clark, T.J.; Hahn, P.G. Evaluating unintended consequences of intentional species introductions and eradications for improved conservation management. Conserv. Biol. 2021, 13734. [CrossRef] [PubMed]

70. Stiling, P. Why do natural enemies fail in classical biological control programs? Am. Entomol. 1993, 39, 31-37. [CrossRef]

71. Schlum, K.A.; Lamour, K.; de Bortoli, C.P.; Banerjee, R.; Emrich, S.J.; Meagher, R.; Pereira, E.; Murua, M.G.; Sword, G.A.; Tessnow, A.E.; et al. Whole genome comparisons reveal panmixia among fall armyworm (Spodoptera frugiperda) from diverse locations. BMC Genom. 2021, 22, 179. [CrossRef] [PubMed]

72. Hay-Roe, M.M.; Meagher, R.L.; Nagoshi, R.N. Effect of fall armyworm Spodoptera frugiperda (Lepidoptera: Noctuidae) strain and diet on oviposition and development of the parasitoid Euplectrus platyhypenae (Hymenoptera: Eulophidae). Biol. Control 2013, 66, 21-26. [CrossRef]

73. Beltrà, A.; Addison, P.; Ávalos, J.A.; Crochard, D.; Garcia-Marí, F.; Guerrieri, E.; Giliomee, J.H.; Malausa, T.; Navarro-Campos, C.; Palero, F.; et al. Guiding classical biological control of an invasive mealybug using integrative taxonomy. PLoS ONE 2015, 10, e0128685. [CrossRef]

74. Desurmont, G.A.; Donoghue, M.J.; Clement, W.L.; Agrawal, A.A. Evolutionary history predicts plant defense against an invasive pest. Proc. Natl. Acad. Sci. USA 2011, 108, 7070-7074. [CrossRef]

75. Martinson, H.M.; Bergmann, E.J.; Venugopal, P.D.; Riley, C.B.; Shrewsbury, P.M.; Raupp, M.J. Invasive stink bug favors naïve plants: Testing the role of plant geographic origin in diverse, managed environments. Sci. Rep. 2016, 6, 32646. [CrossRef]

76. Leskey, T.C.; Nielsen, A.L. Impact of the invasive brown marmorated stink bug in North America and Europe: History, biology, ecology, and management. Annu. Rev. Entomol. 2018, 63, 599-618. [CrossRef]

77. Barringer, L.; Ciafré, C.M. Worldwide feeding host plants of spotted lanternfly, with significant additions from North America. Environ. Entomol. 2020, 49, 999-1011. [CrossRef]

78. Desurmont, G.A.; Harvey, J.; van Dam, N.M.; Cristescu, S.M.; Schiestl, F.P.; Cozzolino, S.; Anderson, P.; Larsson, M.C.; Kindlmann, P.; Danner, H.; et al. Alien interference: Disruption of infochemical networks by invasive insect herbivores. Plant Cell Environ. 2014, 37, 1854-1865. [CrossRef]

79. Casmuz, A.; Juarez, M.L.; Socias, M.G.; Murua, M.G.; Prieto, S.; Medina, S.; Willink, E.; Gastaminza, G. Review of the host plants of fall armyworm, Spodoptera frugiperda (Lepidoptera: Noctuidae). Rev. Soc. Entomol. Argent. 2010, 69, 209-231.

80. Köllner, T.G.; Held, M.; Lenk, C.; Hiltpold, I.; Turlings, T.C.; Gershenzon, J.; Degenhardt, J. A maize (E)- $\beta$-caryophyllene synthase implicated in indirect defense responses against herbivores is not expressed in most American maize varieties. Plant Cell 2008, 20, 482-494. [CrossRef] [PubMed]

81. Svensson, G.P.; Larsson, M.C.; Hedin, J. Attraction of the larval predator Elater ferrugineus to the sex pheromone of its prey, Osmoderma eremita, and its implication for conservation biology. J. Chem. Ecol. 2004, 30, 353-363. [CrossRef] [PubMed]

82. Vaello, T.; Casas, J.L.; Pineda, A.; de Alfonso, I.; Marcos-García, M.Á. Olfactory response of the predatory bug Orius laevigatus (Hemiptera:Anthocoridae) to the aggregation pheromone of its prey, Frankliniella occidentalis (Thysanoptera: Thripidae). Environ. Entomol. 2017, 46, 1115-1119. [CrossRef]

83. Cottrell, T.E.; Landolt, P.J.; Zhang, Q.-H.; Zack, R.S. A chemical lure for stink bugs (Hemiptera: Pentatomidae) is used as a kairomone by Astata occidentalis (Hymenoptera: Sphecidae). Fla. Entomol. 2014, 97, 233-237. [CrossRef]

84. Aukema, B.H.; Raffa, K.F. Selective manipulation of predators using pheromones: Responses to frontalin and ipsdienol pheromone components of bark beetles in the Great Lakes region. Agric. For. Entomol. 2005, 7, 193-200. [CrossRef]

85. Hartfield, E.A.; Harris, M.K.; Medina, R.F. Searching for pheromone strains in the pecan nut casebearer. Entomol. Exp. Appl. 2010, 137, 11-18. [CrossRef]

86. Pelozuelo, L.; Malosse, C.; Genestier, G.; Guenego, H.; Frerot, B. Host-plant specialization in pheromone strains of the European corn borer Ostrinia nubilalis in France. J. Chem. Ecol. 2004, 30, 335-352. [CrossRef]

87. Harris, V.E.; Todd, J.W. Male-mediated aggregation of male, female and 5th-instar southern green stink bugs 1 and concomitant attraction of a tachinid parasite, Trichopoda pennipes. Entomol. Exp. Appl. 1980, 27, 117-126. [CrossRef]

88. Clausen, C.P. Pentatomidae. In Introduced Parasites and Predators of Arthropod Pests and Weeds: A World Review; Agricultural Research Service, US Department of Agriculture: Washington, DC, USA, 1978; p. 23. 
89. Aldrich, J.R.; Oliver, J.E.; Lusby, W.R.; Kochansky, J.P.; Lockwood, J.A. Pheromone strains of the cosmopolitan pest, Nezara viridula (Heteroptera: Pentatomidae). J. Exp. Zool. 1987, 244, 171-175. [CrossRef]

90. Blomquist, G.J.; Tittiger, C.; Jurenka, R. Cuticular hydrocarbons and pheromones of arthropods. In Hydrocarbons, Oils and Lipids: Diversity, Origin, Chemistry and Fate; Springer: Cham, Switzerland, 2020; pp. 213-244.

91. Henneken, J.; Goodger, J.Q.D.; Jones, T.M.; Elgar, M.A. Diet-mediated pheromones and signature mixtures can enforce signal reliability. Front. Ecol. Evol. 2017, 4, 145. [CrossRef]

92. Piskorski, R.; Trematerra, P.; Dorn, S. Cuticular hydrocarbon profiles of codling moth larvae, Cydia pomonella (Lepidoptera: Tortricidae), reflect those of their host plant species. Biol. J. Linn. Soc. 2010, 101, 376-384. [CrossRef]

93. Xue, H.-J.; Wei, J.-N.; Magalhães, S.; Zhang, B.; Song, K.-Q.; Liu, J.; Li, W.Z.; Yang, X.K. Contact pheromones of 2 sympatric beetles are modified by the host plant and affect mate choice. Behav. Ecol. 2016, 27, 895-902. [CrossRef]

94. Otte, T.; Hilker, M.; Geiselhardt, S. Phenotypic plasticity of cuticular hydrocarbon profiles in insects. J. Chem. Ecol. 2018, 44, 235-247. [CrossRef]

95. Geiselhardt, S.; Otte, T.; Hilker, M. The role of cuticular hydrocarbons in male mating behavior of the mustard leaf beetle, Phaedon cochleariae (F.). J. Chem. Ecol. 2009, 35, 1162-1171. [CrossRef]

96. Geiselhardt, S.; Otte, T.; Hilker, M. Looking for a similar partner: Host plants shape mating preferences of herbivorous insects by altering their contact pheromones. Ecol. Lett. 2012, 15, 971-977. [CrossRef]

97. Otte, T.; Hilker, M.; Geiselhardt, S. Phenotypic plasticity of mate recognition systems prevents sexual interference between two sympatric leaf beetle species: Phenotypic plasticity of mate recognition systems. Evolution 2016, 70, 1819-1828. [CrossRef]

98. Fürstenau, B.; Hilker, M. Cuticular hydrocarbons of Tribolium confusum larvae mediate trail following and host recognition in the ectoparasitoid Holepyris sylvanidis. J. Chem. Ecol. 2017, 43, 858-868. [CrossRef]

99. Awater-Salendo, S.; Schulz, H.; Hilker, M.; Fürstenau, B. The importance of methyl-branched cuticular hydrocarbons for successful host recognition by the larval ectoparasitoid Holepyris sylvanidis. J. Chem. Ecol. 2020, 46, 1032-1046. [CrossRef]

100. Hood, G.R.; Jennings, J.H.; Bruzzese, D.J.; Beehler, M.; Schmitt, T.; Feder, J.L.; Etges, W.J. Cuticular hydrocarbon variation among Rhagoletis fruit flies (Diptera: Tephritidae): Implications for premating reproductive isolation and ecological speciation. Ecol. Entomol. 2021, 13101. [CrossRef]

101. Jonsson, M.; Wratten, S.D.; Landis, D.A.; Gurr, G.M. Recent advances in conservation biological control of arthropods by arthropods. Biol. Control 2008, 45, 172-175. [CrossRef]

102. Hunt, L.G.; Dively, G.; Hooks, C.R. Flowering Chamaecrista fasciculata borders enhance natural enemy populations and improve grain quality in field corn. Agric. Ecosyst. Environ. 2021, 306, 107193. [CrossRef]

103. Khan, Z.R.; James, D.G.; Midega, C.A.O.; Pickett, J.A. Chemical ecology and conservation biological control. Biol. Control 2008, 45, 210-224. [CrossRef]

104. Kaplan, I. Attracting carnivorous arthropods with plant volatiles: The future of biocontrol or playing with fire? Biol. Control 2012, 60,77-89. [CrossRef]

105. Rodriguez-Saona, C.; Kaplan, I.; Braasch, J.; Chinnasamy, D.; Williams, L. Field responses of predaceous arthropods to methyl salicylate: A meta-analysis and case study in cranberries. Biol. Control 2011, 59, 294-303. [CrossRef]

106. Zhang, X.; van Doan, C.; Arce, C.C.M.; Hu, L.; Gruenig, S.; Parisod, C.; Hibbard, B.E.; Hervé, M.R.; Nielson, C.; Robert, C.A.; et al. Plant defense resistance in natural enemies of a specialist insect herbivore. Proc. Natl. Acad. Sci. USA 2019, 116, 23174-23181. [CrossRef]

107. Fontes-Puebla, A.A.; Bernal, J.S. Resistance and tolerance to root herbivory in maize were mediated by domestication, spread, and breeding. Front. Plant Sci. 2020, 11, 223. [CrossRef]

108. Joyce, A.L.; Sermeno Chicas, M.; Serrano Cervantes, L.; Paniagua, M.; Scheffer, S.J.; Solis, M.A. Host-plant associated genetic divergence of two Diatraea spp. (Lepidoptera: Crambidae) stemborers on novel crop plants. Ecol. Evol. 2016, 6, 8632-8644. [CrossRef]

109. Bezemer, T.M.; Harvey, J.A.; Cronin, J.T. Response of native insect communities to invasive plants. Annu. Rev. Entomol. 2014, 59, 119-141. [CrossRef]

110. Murphy, S.M. Enemy-free space maintains swallowtail butterfly host shift. Proc. Natl. Acad. Sci. USA 2004, 101, 18048-18052. [CrossRef]

111. Lin, T.; Vrieling, K.; Laplanche, D.; Klinkhamer, P.G.L.; Lou, Y.; Bekooy, L.; Degen, T.; Bustos-Segura, C.; Turlings, T.C.; Desurmont, G.A. Evolutionary changes in an invasive plant support the defensive role of plant volatiles. Curr. Biol. 2021, 31, 3450-3456. [CrossRef] [PubMed]

112. Grosman, A.H.; Van Breemen, M.; Holtz, A.; Pallini, A.; Rugama, A.M.; Pengel, H.; Venzon, M.; Zanuncio, J.C.; Sabelis, M.W.; Janssen, A. Searching behaviour of an omnivorous predator for novel and native host plants of its herbivores: A study on arthropod colonization of eucalyptus in Brazil. Entomol. Exp. Appl. 2005, 116, 135-142. [CrossRef]

113. Knerl, A.; Bowers, M.D. Incorporation of an introduced weed into the diet of a native butterfly: Consequences for preference, performance and chemical defense. J. Chem. Ecol. 2013, 39, 1313-1321. [CrossRef] [PubMed]

114. Haan, N.L.; Bowers, M.D.; Bakker, J.D. Preference, performance, and chemical defense in an endangered butterfly using novel and ancestral host plants. Sci. Rep. 2021, 11, 992. [CrossRef]

115. Singer, M.S.; Carriere, Y.; Theuring, C.; Hartmann, T. Disentangling food quality from resistance against parasitoids: Diet choice by a generalist caterpillar. Am. Nat. 2004, 164, 423-429. [CrossRef] [PubMed] 
116. Harvey, J.A.; Fortuna, T.M. Chemical and structural effects of invasive plants on herbivore-parasitoid/predator interactions in native communities: Invasive plants and multitrophic interactions. Entomol. Exp. Appl. 2012, 144, 14-26. [CrossRef]

117. Fortuna, T.M.; Vet, L.E.M.; Harvey, J.A. Effects of an invasive plant on the performance of two parasitoids with different host exploitation strategies. Biol. Control 2012, 62, 213-220. [CrossRef]

118. Chabaane, Y.; Laplanche, D.; Turlings, T.C.; Desurmont, G.A. Impact of exotic insect herbivores on native tritrophic interactions: A case study of the African cotton leafworm, Spodoptera littoralis and insects associated with the field mustard Brassica rapa. J. Ecol. 2015, 103, 109-117. [CrossRef]

119. Martorana, L.; Foti, M.C.; Rondoni, G.; Conti, E.; Colazza, S.; Peri, E. An invasive insect herbivore disrupts plant volatile mediated tritrophic signalling. J. Pest Sci. 2017, 90, 1079-1085. [CrossRef]

120. Desurmont, G.A.; Pearse, I.S. Alien plants versus alien herbivores: Does it matter who is non-native in a novel trophic interaction? Curr. Opin. Insect Sci. 2014, 2, 20-25. [CrossRef]

121. Medina, R.F.; Dickey, A.M.; Harrison, K.; Miller, G.L. Host-associated differentiation in a pecan and water hickory Aphidomorpha community. Entomol. Exp. Appl. 2017, 162, 366-378. [CrossRef]

122. Glenister, C.; Hoffmann, M.; Ridgway, R.; Inscoe, M. Mass Reared Natural Enemies: Application, Regulation, and Needs; Entomological Society of America: Lanham, MD, USA, 1998.

123. Mackauer, M. Genetic problems in the production of biological control agents. Annu. Rev. Entomol. 1976, 21, 369-385. [CrossRef]

124. Chambers, D.L. Quality control in mass rearing. Annu. Rev. Entomol. 1977, 22, 289-308. [CrossRef]

125. Hopper, K.R.; Roush, R.T.; Powell, W. Management of genetics of biological-control introductions. Annu. Rev. Entomol. 1993, 38, 27-51. [CrossRef]

126. Luck, R.F.; Nunney, L.; Hawkins, B.; Cornell, H. A Darwinian view of host selection and its practical implications. In Theoretical Approaches to Biological Control; Cambridge University Press: Cambridge, UK, 1999; pp. 283-303.

127. Bertin, A.; Pavinato, V.A.C.; Parra, J.R.P. Fitness-related changes in laboratory populations of the egg parasitoid Trichogramma galloi and the implications of rearing on factitious hosts. BioControl 2017, 62, 435-444. [CrossRef]

128. Rojas, M.G.; Morales-Ramos, J.A.; King, E.G. Response of Catolaccus grandis (Hymenoptera: Pteromalidae) to its natural host after ten generations of rearing on a factitious host, Callosobrucus maculatus (Coleoptera: Bruchidae). Environ. Entomol. 1999, 28, 137-141. [CrossRef]

129. Henry, L.M.; Roitberg, B.D.; Gillespie, D.R. Host-range evolution in Aphidius parasitoids: Fidelity, virulence and fitness trade- offs on an ancestral host. Evolution 2008, 62, 689-699. [CrossRef]

130. Unruh, T.; White, W.; Gonzalez, D.; Gordh, G.; Luck, R. Heterozygosity and effective size in laboratory populations of Aphidius ervi [Hym.: Aphidiidae]. Entomophaga 1983, 28, 245-258. [CrossRef]

131. Antwi, J.B.; Sword, G.A.; Medina, R.F. Host-associated differentiation in a highly polyphagous, sexually reproducing insect herbivore. Ecol. Evol. 2015, 5, 2533-2543. [CrossRef]

132. Eubanks, M.D.; Blair, C.P.; Abrahamson, W.G. One host shift leads to another? evidence of host-race formation in a predaceous gall-boring beetle. Evolution 2003, 57, 168-172. [CrossRef]

133. Leung, K.; Ras, E.; Ferguson, K.B.; Ariëns, S.; Babendreier, D.; Bijma, P.; Bourtzis, K.; Brodeur, J.; Bruins, M.A.; Centurión, A.; et al Next-generation biological control: The need for integrating genetics and genomics. Biol. Rev. 2020, 95, 1838-1854. [CrossRef] [PubMed]

134. Kruidhof, H.M.; Kostenko, O.; Smid, H.M.; Vet, L.E.M. Integrating parasitoid olfactory conditioning in augmentative biological control: Potential impact, possibilities, and challenges. Front. Ecol. Evol. 2019, 7, 84. [CrossRef]

135. Roßbach, A.; Löhr, B.; Vidal, S. Does a specialist parasitoid adapt to its host on a new host plant? J. Insect Behav. 2006, 19, 479-495. [CrossRef]

136. Rasmann, S.; Köllner, T.G.; Degenhardt, J.; Hiltpold, I.; Toepfer, S.; Kuhlmann, U.; Gershenzon, J.; Turlings, T.C. Recruitment of entomopathogenic nematodes by insect-damaged maize roots. Nature 2005, 434, 732-737. [CrossRef] [PubMed]

137. Hiltpold, I.; Toepfer, S.; Kuhlmann, U.; Turlings, T.C.J. How maize root volatiles affect the efficacy of entomopathogenic nematodes in controlling the western corn rootworm? Chemoecology 2010, 20, 155-162. [CrossRef]

138. Hiltpold, I.; Baroni, M.; Toepfer, S.; Kuhlmann, U.; Turlings, T.C.J. Selection of entomopathogenic nematodes for enhanced responsiveness to a volatile root signal helps to control a major root pest. J. Exp. Biol. 2010, 213, 2417-2423. [CrossRef] [PubMed]

139. Wang, S.; Miao, X.; Zhao, W.; Huang, B.; Fan, M.; Li, Z.; Huang, Y. Genetic diversity and population structure among strains of the entomopathogenic fungus, Beauveria bassiana, as revealed by inter-simple sequence repeats (ISSR). Mycol. Res. 2005, 109, 1364-1372. [CrossRef]

140. Bracewell, R.R.; Vanderpool, D.; Good, J.M.; Six, D.L. Cascading speciation among mutualists and antagonists in a tree-beetle fungi interaction. Proc. R. Soc. B Biol. Sci. 2018, 285, 20180694. [CrossRef]

141. Simon, J.-C.; Carre, S.; Boutin, M.; Prunier-Leterme, N.; Sabater-Muñoz, B.; Latorre, A.; Bournoville, R. Host-based divergence in populations of the pea aphid: Insights from nuclear markers and the prevalence of facultative symbionts. Proc. R. Soc. B Biol. Sci. 2003, 270, 1703-1712. [CrossRef]

142. Esteve-Gassent, M.D.; Castro-Arellano, I.; Feria-Arroyo, T.P.; Patino, R.; Li, A.Y.; Medina, R.F.; de León, A.A.P.; Rodríguez-Vivas, R.I. Translating ecology, physiology, biochemistry, and population genetics research to meet the challenge of tick and tick-borne diseases in North America. Arch. Insect Biochem. Physiol. 2016, 92, 38-64. [CrossRef] 
143. Malacrinò, A.; Campolo, O.; Medina, R.F.; Palmeri, V. Instar- and host-associated differentiation of bacterial communities in the Mediterranean fruit fly Ceratitis capitata. PLoS ONE 2018, 13, e0194131. [CrossRef] [PubMed]

144. Holt, J.R.; Styer, A.; White, J.A.; Armstrong, J.S.; Nibouche, S.; Costet, L.; Malacrinò, A.; Antwi, J.B.; Wulff, J.; Peterson, G.; et al. Differences in microbiota between two multilocus lineages of the sugarcane aphid (Melanaphis sacchari) in the continental United States. Ann. Entomol. Soc. Am. 2020, 113, 257-265. [CrossRef]

145. Garvey, M.; Bredlau, J.; Kester, K.; Creighton, C.; Kaplan, I. Toxin or medication? Immunotherapeutic effects of nicotine on a specialist caterpillar. Funct. Ecol. 2021, 35, 614-626. [CrossRef]

146. Smilanich, A.M.; Dyer, L.A.; Gentry, G.L. The insect immune response and other putative defenses as effective predictors of parasitism. Ecology 2009, 90, 1434-1440. [CrossRef] [PubMed]

147. Russo, J.; Dupas, S.; Frey, F.; Carton, Y.; Brehelin, M. Insect immunity: Early events in the encapsulation process of parasitoid (Leptopilina boulardi) eggs in resistant and susceptible strains of Drosophila. Parasitology 1996, 112, 135-142. [CrossRef]

148. Kaiser, L.; Dupas, S.; Branca, A.; Herniou, E.; Clarke, C.; Dulac, C.C.; Obonyo, J.; Benoist, R.; Gauthier, J.; Calatayud, P.A.; et al. The Cotesia sesamiae story: Insight into host-range evolution in a Hymenoptera parasitoid and implication for its use in biological control programs. Genetica 2017, 145, 455-468. [CrossRef] 